\title{
Transanal Advancement Flap Repair: The Current Gold Standard for Cryptoglandular Transsphincteric Perianal Fistulas
}

\section{Transanal İlerletme Flep Tekniği: Kriptoglandüler Transsfinkterik Perianal Fistüllerde Güncel Altın Standart}

\author{
(1) David D. E. Zimmerman, (1) Jasper Stijns, (1) Daria K. Wasowicz, @ Kevin W. A. Gottgens \\ Elisabeth-TweeSteden Ziekenhuis Hospital, Department of Surgery, Tilburg, Netherlands
}

\section{IIIIIIII ABSTRACT}

Transanal advancement flap repair has been considered as a treatment modality for transsphincteric perianal fistulas for over a century. Several systematic reviews have shown that this technique is effective in 80 percent of cases with a minimal and predictable effect on continence. The use of thicker flaps has been shown to increase the rate of recovery, but also to increase the rate of continence impairment. Unfortunately, there are few modifiable factors that seem to affect recovery. These include smoking cessation and weight loss. There is no evidence to support the use of diverting stomas. The placement of setons as part of a standardized treatment regimen is not supported by the literature. It is unadvisable to combine flap repair with other techniques.

Keywords: Endorectal, fistula, fistula in ano, transanal advancement flap, transsfincteric

\section{||||||||||| ÖZ}

Transanal ilerletme flep tekniği, yüz yıldan fazla süredir transsfinkterik perianal fistüller için bir tedavi yöntemi olarak görülmüştür. Çeşitli sistematik derlemeler, bu tekniğin kontinans üzerinde minimal ve öngörülebilir bir etki ile olguların yüzde 80'inde etkili olduğunu göstermiştir. Daha kalın fleplerin kullanımının iyileşme oranını artırdığı, ancak aynı zamanda kontinans bozulma oranını da artırdığı gösterilmiştir. Ne yazık ki, iyileşmeyi etkileyebilecek az sayıda değiştirilebilir faktör vardır. Sigarayı bırakma ve kilo verme bunların arasında sayılabilir. Saptırıcı stomaların kullanımını destekleyen herhangi bir kanıt yoktur. Standart tedavi rejiminin bir parçası olarak setonların yerleştirilmesi literatür tarafından desteklenmemektedir. Flep onarımını diğer tekniklerle birleştirmek tavsiye edilmez.

Anahtar Kelimeler: Endorektal, fistül, anal fistül, transanal ilerletme flebi, transsfinkterik

\section{Introduction}

\section{Historic Considerations}

To the best of our knowledge, transanal advancement flap repair (TAFR) for perianal fistulas was first described by Elting. ${ }^{1}$ Interestingly, he stated that "while the treatment of practically every other surgical malady has been improved in the past few decades, the treatment of fistula in ano remains about where it was twenty years ago, and the general results of such treatment are but little if any more satisfactory than they were then". Interestingly, a few surgeons would be surprised if this statement was expressed today. Throughout the years, many modifications have been made to the technique, originally described by Elting. ${ }^{1}$ Nonetheless, most authors have published their techniques under a similar name ("endorectal" or "transanal" advancement flap). Elting. ${ }^{1}$ described a large series of 96 patients with perianal fistula. The surgery was successful in all cases and he described fecal incontinence in only four cases (4\%). Several small series were published throughout the $20^{\text {th }}$ century, but the first

Address for Correspondence/Yazışma Adresi: David D. E. Zimmerman MD, 
large series in recent years was published by Aguilar et al. ${ }^{2}$ Interestingly, like Elting. ${ }^{1}$ he described a very dissimilar flap design to the flap most authors have described in the past 20 years. We have published our technique extensively in earlier reports. ${ }^{3,4}$

\section{Effectiveness of Technique}

Even though the reported recovery rate of TAFR varies widely, ranging from $30 \%$ to $100 \%$, most author surgeons state an approximately $2 / 3$ improvement rate for their patients. As with many techniques, the reported initial recovery rates are very high. The large series by Aguilar et al. $^{2}$ in the 1980s described an almost perfect recovery rate of $98 \%$. This high recovery rate motivated many others to start utilizing the technique in order to improve the outcome of fistula surgery. Unfortunately, other authors failed to reproduce these results. Decreased success rates were published in the 1990s, reporting more realistic recovery rates varying between 68 and $87 \% .^{4,5,6}$ In an excellent review of 35 studies including over 2000 patients, Soltani and Kaises ${ }^{7}$ presented a weighted average recovery rate of $80.8 \%$ for cryptoglandular fistulas. A later similar review by Balciscueta et al. ${ }^{8}$ found a similar pooled rate of recurrence of $21 \%$, although it included several large-scale new studies and ignored low-quality studies. Due to these findings, we think that the expected recovery rate of TAFR is around $80 \%$.

\section{Impact on Fecal Continence}

Interestingly, the first series at the end of the $20^{\text {th }}$ century hardly entail detailed reports of the impact on fecal continence. The series of Aguilar et al. ${ }^{2}$ described an impairment of continence in approximately $10 \%$ of cases, whereas Schouten et al. ${ }^{4}$ reported a significantly higher rate of impaired continence of $35 \%$. It is unclear why exactly patients who undergo TAFR may encounter impaired continence. Although the external anal sphincter is preserved in all patients, they frequently experience minor effects on fecal continence. Although overt fecal incontinence is rare, minor impairment is a frequent finding. Aguilar attributed this effect to the inclusion of circular muscle fibers in the flap. ${ }^{2}$ Zimmerman et al. ${ }^{9}$ postulated that the use of the Parks retractor was a major contributing factor. This phenomenon was also described by other authors. ${ }^{10}$ It is difficult to draw meaningful conclusions on this subject; however, there are some indications in the literature that the use of this retractor is a major contributing factor to fecal continence impairment. It is rare for published results of flap repair to contain detailed information about the effect on fecal continence. However, authors describing the use of different retractors (such as Hill-Ferguson, Eisenhammer or Scott retractors) reported a rate of impaired continence varying between 0 and $12 \%$, whereas authors who used the Parks retractor reported a rate of impaired continence varying between 28 and $40 \%{ }^{4,}, 11,12,13,14,15$ Moreover, in our early study, we compared the use of the Parks retractor to the use of the Scott retractor, and we found a statistically significant difference both in Rockwood Fecal Incontinence Severity index and postoperative anal resting pressure. ${ }^{9}$ Finally, the rate of impaired continence in our patients decreased from $35 \%$ to $4 \%$ after discontinuation of the use of Parks retractor. ${ }^{4,16}$ The review of Soltani and Kaiser $^{7}$ calculated a weighted average incontinence rate of $13 \%$. In conclusion, approximately one in 10 patients will encounter impaired continence after this surgery. The inclusion of circular muscle fibers and the use of Parks retractor may play a major contributing role in this regard.

\section{Aspects of Surgical Technique}

\section{Type of Flap}

The original description of the technique (as described by both Elting ${ }^{1}$ and Aguilar et al. ${ }^{2}$ ) encompasses the creation of an elliptical (or even straight?) flap as opposed by more recent authors, who create a more rhomboid flap. The main difference between these techniques is the vertical incisions on the lateral sides of the flap (Figure 1). These authors do not describe why they chose different types of flap design. Most likely, training or trainers may play a role in this. Not all authors have described their exact choice of flap type; therefore, it is impossible to draw any meaningful conclusions into the benefit of one flap type over the other. Yellinek et al. ${ }^{17}$ performed an interesting study in which they compared the results of a heterogeneous group of fistula repairs (including many different types and etiologies of fistulas) by a rather large group of six colorectal surgeons who rarely performed advancement flap repair (about two procedures per surgeon per year). They compared patients with a rhomboid flap to patients with an elliptical flap. They concluded that there was no difference between these two groups of patients in terms of recovery. On theoretical grounds, it can be advocated that elliptical flaps allow better blood supply to the tip of the flap due to the absence of corners, however, the literature does not support this belief
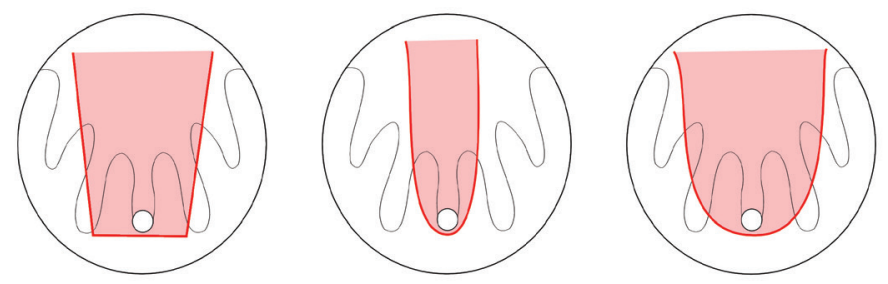

Figure 1. a) Elliptical flap incision, b) rhomboid flap incision. Red line depicts incision, red shaded area depicts submucosal dissection limits 
sufficiently, so we recommend that one should not choose the type of flap on the grounds of expected improved recovery. ${ }^{17}$ In our experience, when a relatively large part of the distal end of the flap has to be excised (due to suppuration), a rhomboid flap is usually indicated in order to achieve a tension-free closure.

\section{Shape of Flap}

Over the last two decades, various different shapes have been described, including wide-angular flaps (Figure 2a), relatively narrow round flaps (Figure $2 b$ ), and relatively wide round flaps (Figure 2c) ${ }^{4,12,18}$ It is rare for authors to describe the reason for their choice of flap shape. Moreover, most often flap shape has to be deduced from schematic drawings supplied with the article. Therefore, it is impossible to draw meaningful conclusions about the preferred shape of the flap.

\section{Thickness of Flap}

More robust research has been performed on the optimal thickness of the flap. Different methods have been described over time ranging from the formation of pure mucosal flaps to the use of full thickness rectal wall. Both prospective and retrospective investigations were performed. The difference in approach was first identified by the Dubsky et al. ${ }^{19}$ Their retrospective review suggested an improvement in recovery rates without higher rates of impaired continence after full mobilization of the rectal wall. Khafagy et al. ${ }^{20}$ performed a prospective analysis and randomized flap designs consisting of mucosa and submucosa with (Group 1) or without (Group 2) inclusion of circular muscle fibers. They noticed a statistically significant difference between these two groups in terms of recurrence in favor of full thickness flaps. The recovery rate in Group 1 was $90 \%$, whereas only $60 \%$ recovered in Group 2. Even though there was a minor difference in terms of impairment of continence $(0 \%$ vs. $10 \%$ ) in favor of Group 2, this difference did not reach statistical significance. Balciscueta et al. ${ }^{8}$ investigated this issue by performing a systematic review and meta-analysis. This group meticulously investigated reports on full and partial thickness flaps and their influence on recovery and
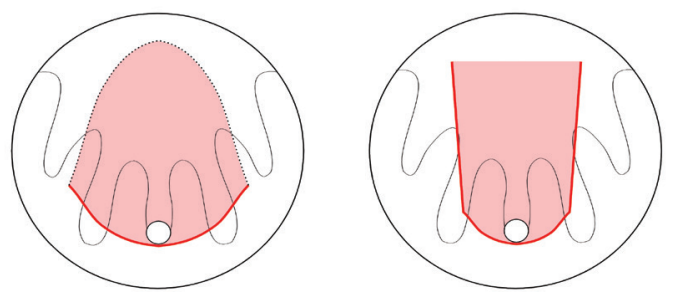

Figure 2. a) Wide angular rhomboid flap, b) narrow round rhomboid flap, c) wide round rhomboid flap. Red line depicts incision, red shaded area depicts submucosal dissection limits fecal continence. They identified not two but three types of flaps, namely mucosal, partial thickness and full thickness flaps. Some criticism on this classification is warranted in our opinion, since many reports do not offer detailed descriptions of their technique. Moreover, most reports are retrospective and many describe surgeries by different surgeons, making full standardization of technique unlikely. Nonetheless, this systematic review elegantly shows an explicit suggestion that there is a strong correlation between the increasing thicknesses of the flap and improved recovery rates. It is noteworthy that they also showed a higher rate of continence impairment after the use of thicker flaps, even though statistical significance was not reached. Intuitively, it is easy to accept that thicker flaps may lead to both high recovery rates and poorer continence. It is however not entirely clear why it affects continence. Khafagy et al. ${ }^{20}$ performed anorectal manometry and did not identify differences between the effects of the two techniques on resting- or squeeze pressure. It is likely that all intraanal surgery will have an effect on anorectal continence; however, it may be minor. As stated before, selective use of retractors may play a role. Also, some surgeons advocate that the type of anesthesia (resulting in different levels of pelvic relaxation) may play a role. No objective data about this issue are available. Sensibility of the anal verge may be impaired after formation of advancement flap, possibly deteriorating fecal continence in some patients. More extensive dissection when creating thicker flaps may contribute to this. In conclusion, it seems clear that creating advancement flaps that encompass circular fibers, or even the full thickness of the rectal wall will lead to higher recovery rates at the cost of a seemingly higher rate of (minor) continence impairment. We advocate the use of thicker flaps where possible, while recognizing the fact that individualized flap design, based on the pathology and anatomy of the patient is mandatory.

\section{Addition of Accessory Techniques (Or the "Icarus Syndrome")}

An interesting phenomenon observed in many different types of fistula surgeries is the desire of individual authors to combine different treatment modalities in order to improve the outcomes of said treatment. Regrettably, these additions dilute the available data on operative techniques, often before their exact role is clarified. Moreover, authors often attempt to improve their own imperfect results when compared to initial reports without reporting the imperfect results, thereby inadvertently inflating the publicly available results. Ellis and Clark ${ }^{21}$ published a small series of 60 patients who underwent anocutaneous or mucosal advancement flap repair, and in half of these patients, an attempt was made to improve the outcomes by adding obliteration of the external tract with fibrin glue. A contrary effect was noted. The authors concluded that the study failed to improve outcome, 
but interestingly they did not consider that obliteration of the tract with fibrin glue might also have a negative effect. Interestingly, not only were the outcomes of the flap repair poorer than expected, the recovery rates were also much worse than those initially published for fibrin glue treatment (75 to 81\%).22,23 Other authors have also attempted to augment the putcomes of flap repair by obliterating the external fistula tract. Several authors reported small series of combined treatment of TAFR and fistula plugs, yielding varying results (recovery rates between $25-75 \%$ ). ${ }^{24,25,26}$, These outcomes are unimpressive compared to series reporting the outcome of plug alone. ${ }^{27}$ An attempt by our group to augment outcomes of flap repair by obliterating the external fistula tract using BioGlue ${ }^{\circledast}$ was discontinued after including eight patients in a pilot study and noticing adverse events (severe pain and/or abscess formation) in seven patients. Wilhelm et al. ${ }^{28}$ published their large series of patients who underwent laser-assisted fistula treatment (LAFT). Fifty-three patients underwent LAFT in combination with mucosal advancement flap repair. Primary recovery was achieved in 35 patients (67\%). This recovery rate does not seem to differ from the reported recovery rates of Giamundo et al. ${ }^{29}$ through LAFT alone (without the addition of a flap repair). ${ }^{30}$ Finally, the outcomes of flap repair has also been attempted to be augmented by additional ligation of the intersphincteric fistula tract (LIFT). van Onkelen et al. ${ }^{31}$ disappointingly described that recovery was observed in only 21 patients (51\%) out of 41 patients. Again, this recovery rate was lower than expected in the TAFR as well as what has been reported in studies using LIFT alone (a reported pooled recovery rate of $71 \%$ ). ${ }^{32}$ These findings are summarized in Figure 3. In conclusion, it should be noted that, to date, no additional treatment to TAFR has ever shown improved results, both when compared to the expected results of TAFR as well as to the expected results of the augmentative procedure. In our opinion, attempts at augmenting the well-investigated and predictable results of TAFR should be undertaken with extreme caution and should only be attempted when a very solid theoretical basis for the expected improvement of outcomes can be formulated. Furthermore, these attempts should be considered experimental and can only be undertaken within studies, after careful and detailed patient informed consent and shared decision making where applicable.

\section{Factors Contributing to Successful Recovery}

Several studies have investigated which factors contribute to recovery or failure of TAFR (Table 1). Upon reviewing these different factors, it is clear that there is no consensus on which factors can predict failure. Besides, different authors used different definitions and aspects of complexity to describe the fistulas they treated.

\section{Fistula-related Factors}

Even though several authors have investigated the effect of horseshoe extensions on the recurrence rate, only van Onkelen et al. ${ }^{33}$ found a statistically significant negative effect of the presence of horseshoe extensions. Intuitively, one would easily understand that this factor is effective. However, other authors did not identify fistula complexity as a negative contributing factor.

\section{Patient-related Factors}

Several patient-related aspects are clearly not negative predictors. Several authors have investigated the effect of gender, age, previous seton drainage, alcohol consumption and diabetes and found no association with negative outcome. Thus, the available evidence suggests that these factors do not play a role. However, several factors are matter for debate. First, we identified smoking as a negative predictive factor. ${ }^{34}$ We also showed a statistically significant effect of the number of cigarettes smoked per day on the recovery rate. This finding was confirmed by Ellis and Clark ${ }^{35}$ Moreover, we showed a decreased blood flow using laser doppler flowmetry in transanal advancement flaps in smokers. ${ }^{36}$ However, this factor has been extensively investigated by several other authors who did not identify smoking as a negative predictor. Interestingly, a later study by our own group also did not find a significant difference between smokers and non-smokers. It is unclear why this difference occurred. Possibly, patient counseling (concerning smoking cessation) after the initial publication played a role. A similar debate exists about obesity. Obesity was identified as an independent negative predictor of outcome



Figure 3. The impact of augmentative additional procedures have never shown to be beneficial

EHR: Expected healing rate, HR: Healing rate, LAFT: Laser assisted fistula treatment, LIFT: Ligation of the intersphincteric fistula tract 
by 2 research groups (Table 1$)^{37,38}$ but was discredited by three others. ${ }^{33,36,39}$ In our opinion, TAFR can be considerably more challenging in obese patients, so there may definitely be a rationale behind this factor. Unfortunately, due to conflicting evidence as well as the difficulty of intervening, this factor does not seem to be a worthwhile modifiable factor. In conclusion, after extensive research over the past 15 years, no undisputed realistically modifiable factors seem to exist. The one possible exception is the smoking status of the patient. Even if the value of this negative predictive factor was debated, a dose-response relation was shown and a pathophysiologic basis was demonstrated. Moreover, this factor is modifiable (it is often possible for patients to discontinue smoking perioperatively). In our opinion, it would be helpful to inform patients about their smoking behavior and advise them to quit smoking. If the fistula repair will not be performed on short notice, weight loss may be considered as well.

\section{Effect of Covering Ostomy}

Sonoda et al. ${ }^{40}$ compared patients who underwent flap repair with and without a covering colostomy in a heterogeneous retrospective group of patients. Sixty-four patients underwent TAFR with a covering stoma, resulting in a recovery rate of $72 \%$. Twenty-five patients had a covering colostomy. In these patients, TAFR was only $60 \%$ successful. Even though this difference was not statistically significant, and it seems likely the more challenging cases may have been offered a stoma, this study did not suggest an advantage of a covering stoma. Similar findings were reported by Mizrahi et al. ${ }^{41}$ even though they had only three patients who had a covering ostomy.

\section{The "Seton Paradox"}

Interestingly, as stated before, none of the authors who investigated the role of preoperative seton drainage showed a statistically significant higher recovery rate in patients in whom a seton was placed before undergoing TAFR. Our group has reported on this subject several times throughout the years (Figure 4)..$^{33,34,42}$ Even though these investigations have led us to refrain from prior seton placement more frequently (Figure 4), still a considerable percentage of patients will undergo seton drainage before TAFR either in the referring hospital or because of excessive inflammation on preoperative magnetic resonance imaging. Paradoxically, this suggests that the most difficult cases will

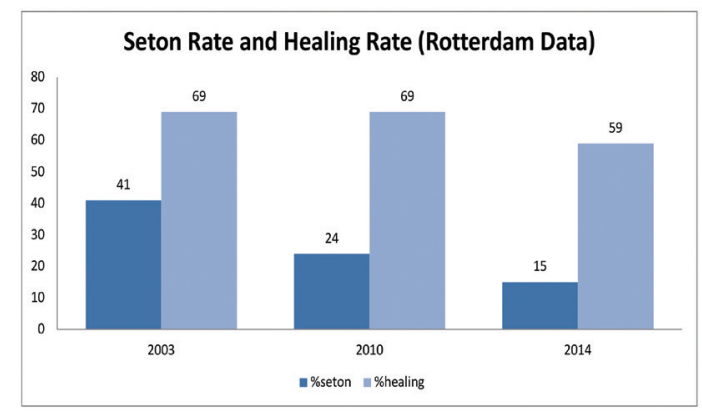

Figure 4. The Rotterdam data concerning prior seton drainage and healing

Table 1. The results of investigations conducted by different authors about the value of different contributing factors

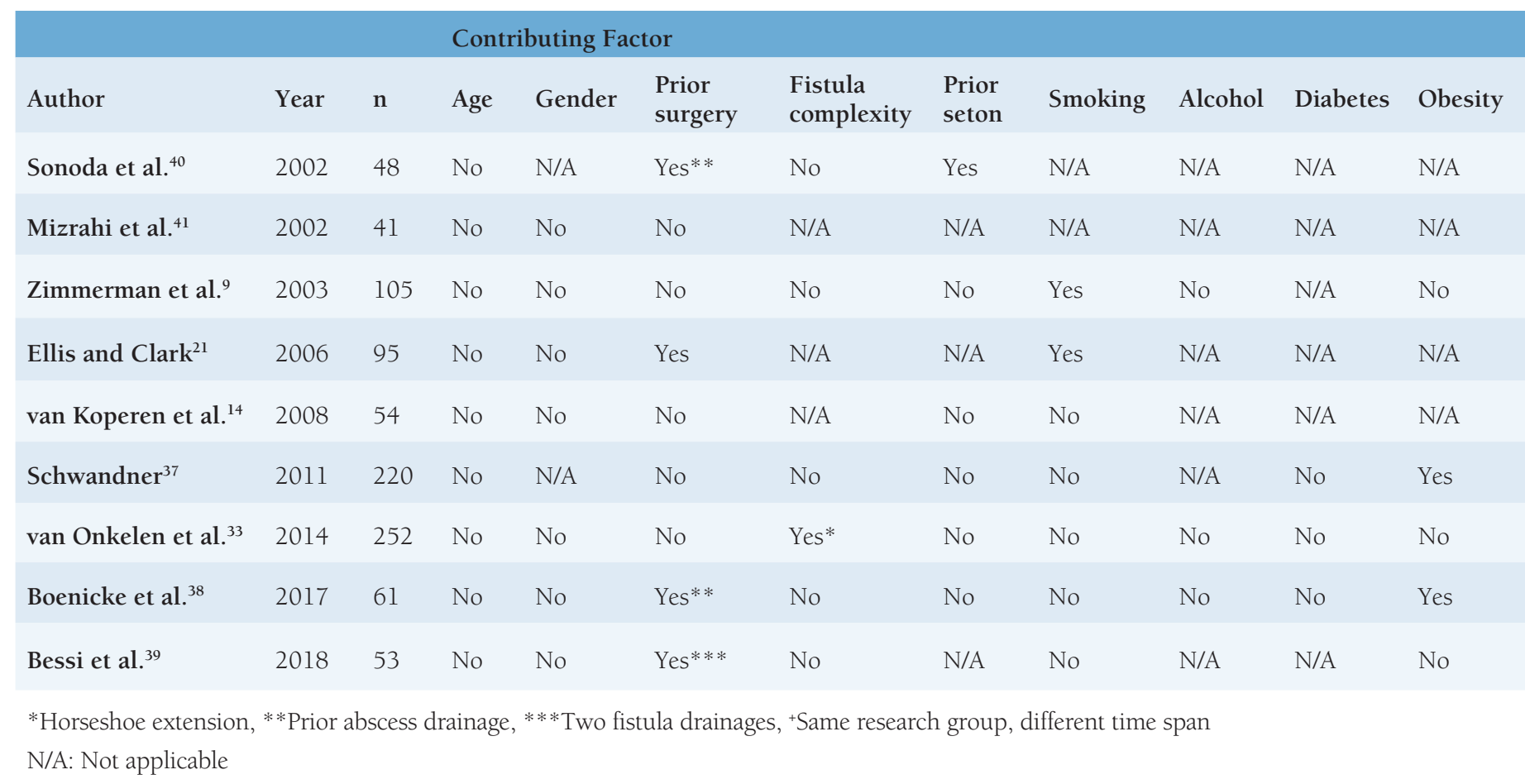


be prone to undergo seton drainage. Remarkably, not only the recovery rate in these patients was not higher than in patients without prior seton drainage, some authors have found it to be lower. ${ }^{40}$ Seton placement prior to TAFR is a well-accepted treatment regimen. Many surgeons advocate seton placement as an important preparatory step before flap repair. Due to the reasonable use of setons, good results can be obtained in the more complex group of patients. In addition to the conclusion that the benefit of previous seton drainage has not been proven and therefore questionable, it is very hard to draw meaningful conclusions from the available literature. In our opinion, seton placement may still be part of an adequate treatment plan. A thorough curettage followed by placement of a comfortable seton may reduce the amount of active inflammation and thereby minimize the size of external wounds at a later time. However, there should be a good reason for seton placement. The placement of setons as part of a standardized treatment regimen is not supported by the literature in our opinion.

In conclusion, TAFR is a well-investigated technique that yieldsgoodresultsin the treatment of perianal cryptoglandular fistulas. It may be expected that $80 \%$ of fistulas will recover after TAFR. The effect on fecal continence is predictable and will affect about $13 \%$ of patients. We advocate the use of thicker flaps, where possible. There are few modifiable factors that seem to affect recovery. Smoking cessation and weight loss may be considered. There is no evidence to support the use of diverting stomas. The placement of setons as part of a standardized treatment regimen is not supported by the literature. It is unadvisable to combine flap repair with other techniques.

\section{Ethics}

Peer-review: Internally peer-reviewed.

\section{Authorship Contributions}

Surgical and Medical Practices: D.D.E.Z., K.G., D.K.W., Concept: D.D.E.Z., K.W.A.G, D.K.W., J.S., Design: D.D.E.Z., Data Collection or Processing: D.D.E.Z., Analysis or Interpretation: D.D.E.Z., Literature Search: D.D.E.Z., Writing: D.D.E.Z., K.W.A.G., J.S.

Conflict of Interest: No conflict of interest was declared by the authors.

Financial Disclosure: The authors declared that this study received no financial support.

\section{References}

1. Elting AW. X. The Treatment of Fistula in Ano: With Especial Reference to the Whitehead Operation. Ann Surg 1912;56:744-752.

2. Aguilar PS, Plasencia G, Hardy TG Jr, Hartmann RF, Stewart WR Mucosal advancement in the treatment of anal fistula. Dis Colon Rectum $1985 ; 28: 496-498$
3. Zimmerman DDE. Transanal advancement flap repair; step-by-step guide for trainees - a video vignette (ESCP trainee video). Colorectal Dis 2019;21:121.

4. Schouten WR, Zimmerman DD, Briel JW. Transanal advancement flap repair of transsphincteric fistulas. Dis Colon Rectum 1999;42:1419-1422.

5. Kodner IJ, Mazor A, Shemesh EI, Fry RD, Fleshman JW, Birnbaum EH. Endorectal advancement flap repair of rectovaginal and other complicated anorectal fistulas. Surgery 1993;114:682-689.

6. Ozuner G, Hull TL, Cartmill J, Fazio VW. Long-term analysis of the use of transanal rectal advancement flaps for complicated anorectal/vaginal fistulas. Dis Colon Rectum 1996;39:10-14.

7. Soltani A, Kaiser AM. Endorectal advancement flap for cryptoglandular or Crohn's fistula-in-ano. Dis Colon Rectum 2010;53:486-495.

8. Balciscueta Z, Uribe N, Balciscueta I, Andreu-Ballester JC, Garcia-Granero E. Rectal advancement flap for the treatment of complex cryptoglandular anal fistulas: a systematic review and meta-analysis. Int J Colorectal Dis 2017:32:599-609.

9. Zimmerman DD, Gosselink MP, Hop WC, Darby M, Briel JW, Schouten WR. Impact of two different types of anal retractor on fecal continence after fistula repair: a prospective, randomized, clinical trial. Dis Colon Rectum 2003; 46:1674-1679.

10. van Tets WF, Kuijpers JH, Tran K, Mollen R, van Goor H. Influence of Parks' anal retractor on anal sphincter pressures. Dis Colon Rectum 1997:40:1042-1045

11. Ortiz H, Marzo M, de Miguel M, Ciga MA, Oteiza F, Armendariz P. Length of follow-up after fistulotomy and fistulectomy associated with endorectal advancement flap repair for fistula in ano. Br J Surg 2008;95:484-487.

12. Hyman N. Endoanal advancement flap repair for complex anorectal fistulas. Am J Surg 1999;178:337-340.

13. Perez F, Arroyo A, Serrano P, Sanchez A, Candela F, Perez MT, Calpena R. Randomized clinical and manometric study of advancement flap versus fistulotomy with sphincter reconstruction in the management of complex fistula-in-ano. Am J Surg 2006;192:34-40.

14. van Koperen PJ, Bemelman WA, Bossuyt PM, Gerhards MF, Eijsbouts QA, van Tets WF, Janssen LW, Dijkstra FR, van Dalsen AD, Slors JF. The anal fistula plug versus the mucosal advancement flap for the treatment of anorectal fistula (PLUG trial). BMC Surg 2008;8:11

15. Koehler A, Risse-Schaaf A, Athanasiadis S. Treatment for horseshoe fistulasin-ano with primary closure of the internal fistula opening: a clinical and manometric study. Dis Colon Rectum 2004:47:1874-1882.

16. Mitalas LE, Gosselink MP, Zimmerman DD, Schouten WR. Repeat transanal advancement flap repair: impact on the overall healing rate of high transsphincteric fistulas and on fecal continence. Dis Colon Rectum 2007;50:1508-1511

17. Yellinek S, Krizzuk D, Moreno Djadou T, Lavy D, Wexner SD. Endorectal advancement flap for complex anal fistula: does flap configuration matter? Colorectal Dis 2019;21:581-587.

18. Willis S, Rau M, Schumpelick V. [Surgical treatment of high anorectal and rectovaginal fistulas with the use of transanal endorectal advancement flaps]. Chirurg 2000;71:836-840.

19. Dubsky PC, Stift A, Friedl J, Teleky B, Herbst F. Endorectal advancement flaps in the treatment of high anal fistula of cryptoglandular origin: fullthickness vs. mucosal-rectum flaps. Dis Colon Rectum 2008;51:852-857.

20. Khafagy W, Omar W, El Nakeeb A, Fouda E, Yousef M, Farid M. Treatment of anal fistulas by partial rectal wall advancement flap or mucosal advancement flap: a prospective randomized study. Int J Surg 2010;8:321325.

21. Ellis CN, Clark S. Fibrin glue as an adjunct to flap repair of anal fistulas: a randomized, controlled study. Dis Colon Rectum 2006;49:1736-1740.

22. Cintron JR, Park JJ, Orsay CP, Pearl RK, Nelson RL, Abcarian H. Repair of fistulas-in-ano using autologous fibrin tissue adhesive. Dis Colon Rectum 1999:42:607-613. 
23. Sentovich SM. Fibrin glue for all anal fistulas. J Gastrointest Surg 2001;5:158-161.

24. Sugrue J, Mantilla N, Abcarian A, Kochar K, Marecik S, Chaudhry V, Mellgren A, Nordenstam J. Sphincter-Sparing Anal Fistula Repair: Are We Getting Better? Dis Colon Rectum 2017;60:1071-1077.

25. Borreman P, de Gheldere C, Fierens J, Vanclooster P. Can a flap help the plug ? Or vice versa ? Proposing a combined sphincter-sparing anal fistula repair. Acta Chir Belg 2014;114:376-380.

26. Mitalas LE, van Onkelen RS, Gosselink MP, Zimmerman DD, Schouten WR. The anal fistula plug as an adjunct to transanal advancement flap repair. Dis Colon Rectum 2010;53:1713.

27. Göttgens KW, Smeets RR, Stassen LP, Beets G, Breukink SO. Systematic review and meta-analysis of surgical interventions for high cryptoglandular perianal fistula. Int J Colorectal Dis 2015;30:583-593.

28. Wilhelm A, Fiebig A, Krawczak M. Five years of experience with the $\mathrm{FiLaC}^{\mathrm{TM}}$ laser for fistula-in-ano management: long-term follow-up from a single institution. Tech Coloproctol 2017;21:269-276.

29. Giamundo P, Esercizio L, Geraci M, Tibaldi L, Valente M. Fistula-tract Laser Closure ( $\mathrm{FiLaC}^{\mathrm{TM}}$ ): long-term results and new operative strategies. Tech Coloproctol 2015;19:449-453.

30. Stijns J, Wasowicz DK, Zimmerman DDE. Does laser fistuloplasty (FiLaC ${ }^{\text {TM}}$ ) offer any benefit over surgical closure of the internal orifice? Tech Coloproctol 2017;21:489-490.

31. van Onkelen RS, Gosselink MP, Schouten WR. Is it possible to improve the outcome of transanal advancement flap repair for high transsphincteric fistulas by additional ligation of the intersphincteric fistula tract? Dis Colon Rectum 2012;55:163-166.

32. Yassin NA, Hammond TM, Lunniss PJ, Phillips RK. Ligation of the intersphincteric fistula tract in the management of anal fistula. A systematic review. Colorectal Dis 2013;15:527-535.
33. van Onkelen RS, Gosselink MP, Thijsse S, Schouten WR. Predictors of outcome after transanal advancement flap repair for high transsphincteric fistulas. Dis Colon Rectum 2014:57:1007-1011.

34. Zimmerman DD, Delemarre JB, Gosselink MP, Hop WC, Briel JW, Schouten WR. Smoking affects the outcome of transanal mucosal advancement flap repair of trans-sphincteric fistulas. Br J Surg 2003;90:351-354.

35. Ellis CN, Clark S. Effect of tobacco smoking on advancement flap repair of complex anal fistulas. Dis Colon Rectum 2007;50:459-463.

36. Zimmerman DD, Gosselink MP, Mitalas LE, Delemarre JB, Hop WJ, Briel JW, Schouten WR. Smoking impairs rectal mucosal bloodflow--a pilot study: possible implications for transanal advancement flap repair. Dis Colon Rectum 2005;48:1228-1232.

37. Schwandner O. Obesity is a negative predictor of success after surgery for complex anal fistula. BMC Gastroenterol 2011;11:61.

38. Boenicke L, Karsten E, Zirngibl H, Ambe P. Advancement Flap for Treatment of Complex Cryptoglandular Anal Fistula: Prediction of Therapy Success or Failure Using Anamnestic and Clinical Parameters. World J Surg 2017:41:2395-2400.

39. Bessi G, Siproudhis L, Merlini l'Heritier A, Wallenhorst T, Le Balc'h E, Bouguen G, Brochard C. Advancement flap procedure in Crohn and non-Crohn perineal fistulas: a simple surgical approach. Colorectal Dis 2019;21:66-72

40. Sonoda T, Hull T, Piedmonte MR, Fazio VW. Outcomes of primary repair of anorectal and rectovaginal fistulas using the endorectal advancement flap. Dis Colon Rectum 2002;45:1622-1628.

41. Mizrahi N, Wexner SD, Zmora O, Da Silva G, Efron J, Weiss EG, Vernava AM 3rd, Nogueras JJ. Endorectal advancement flap: are there predictors of failure? Dis Colon Rectum 2002;45:1616-1621.

42. Mitalas LE, van Wijk JJ, Gosselink MP, Doornebosch P, Zimmerman DD, Schouten WR. Seton drainage prior to transanal advancement flap repair: useful or not? Int J Colorectal Dis 2010;25:1499-1502. 